\title{
Reflection on Talent Cultivation Mode of Higher Vocational Art and Design Education in New Era
}

\author{
Lei Zhang \\ School of Art and Design \\ Huanghe Science and Technology College \\ Zhengzhou, China 450046 \\ E-mail: 12901456@qq.com
}

\begin{abstract}
This paper has presented a systemic description on talent cultivation mode of higher vocational art \& design education from longitudinal and transverse perspectives using the method of theoretical research and case analysis in combination with comparison and conclusion, and has put forward an assumption about establishing a talent cultivation mode of higher vocational art \& design education in new era in combination with practices based on the problems existing in original talent cultivation mode.
\end{abstract}

Keywords-higher vocational education; cultivation; mode

\section{INTRODUCTION}

The talents cultivated by higher vocational art \& design education may be integrated with a variety of industries and categories; especially its new breakthrough of traditional art category has generated new talents by integrating with other industries. As for major development, we should continuously make innovation in accordance with market demand based on setting up such ten majors as Artwork Design, Accessory Design, Costume Design, Furniture Design, Interior Decoration Design, Advertising Design, Product Packaging Design, Stage Design, Print Media \& Television Animation Design, and Environmental Art Design.

\section{OUTSTANDING PROBLEMS IN CURRENT CHINA'S Cultivation Mode of Higher Vocational ART \& DESIGN TALENTS}

Relevant colleges are deepening their education reform but with an extremely unbalanced development, and it is inconsistent with the rapidly developing market economy as China is a late starter of higher vocational art \& design education. Currently, outstanding problems existing in higher vocational art \& design education are as below:

\section{A. Disconnection Between Cultivation Objective, Cultivation Standard and the Market Demand, with Features Non-Displayed}

Higher vocational art \& design education mainly cultivate technology applied talents, with the practical, skillful and occupational talents it cultivated as its feature and strength. Among which, the essential property of higher vocational education is occupational, requiring importance shall be attached to cultivation of comprehensive occupational ability in the teaching process; skillful is their inherent "birthmark", requiring the students cultivated shall have a strong operational ability; practical requires the students cultivated shall be available in any circumstances and can be retained. Of course, various colleges shall further explore their individuality while displaying generality, without ignoring their features at regional and local levels. Locality is not only the requirements for higher vocational education by the times, but also the historical responsibility for the regional economic construction of art \& design education services. The occupational classification and standard for art \& design is quite clear, however, the investigation we have conducted indicates that currently, talent cultivation objective of various higher vocational colleges is somewhat of vague without the features presenting completely.

\section{B. Phenomena of Knowledge Aging, Methods Outdated,}

Disconnection Between Theory and Practice Existing in Teaching Contents and Teaching Methods Etc.

Teachers have followed the teaching methods of academic education for adult education for higher diploma of higher vocational education as it is a late starter; meanwhile, their understanding on the principles of "technology application" and "necessary, sufficient" as defined for higher vocational education is simple and unilateral with weak academic nature of teaching and research. And the teachers don't know much about production and social reality, lacking of practical experience with disconnection of theory and practice. Besides, the curriculum structure is unreasonable, with low proportion of basic theory and major curriculum, and the students is short of sustainable development ability without capability for further development. The students cultivated by higher vocational education with simple skills and narrow knowledge scope are short of the capability for further social development and scientific and technological progress, and have difficulty in adapting to demands for social development in future. 


\section{Lack of Cultivation Mechanism and Non-Established Practical Teaching System Are no Good for Development Of Students' Personality and Creativity}

The characteristics of art \& design major in higher vocational education have determined that emphasis shall be put on strengthening the practical teaching with organic combination of teaching, learning and practicing during the teaching reform process, and continually to deepen the practical teaching reform of art \& design major. However, China's occupational education has deeply affected by traditional teaching methods with the class teaching as main method, which goes against students' development of personality and creativity. Therefore, in the teaching segment of higher vocational art \& design education, importance shall be attached to strengthening the construction of type, organizational form, evaluation and management of practical teaching. As we all know, the general objective of art \& design education shall be realized by optimizing the teaching system of theory and practice, strengthening the practical teaching reform, intensifying the cultivation of critical abilities necessary for occupation. And it is a must to make our teaching contents, teaching methods, teaching means in line with social demands and technology development, and to make the cultivated students more special with the advantage of sustainable development.

\section{Construction of Teaching Staff Needs to Be Strengthened Constantly, and the Structure Remains to Be Improved}

Currently, the sources of teachers of higher vocational colleges are mainly divided into three categories due to various historical reasons: firstly, teachers transformed from the original adult colleges; secondly, teachers promoted from technical secondary schools; thirdly, regular college graduates introduced in recent years. While having their own features and advantages, these three types of teachers also reveal their weakness and deficiency in various aspects. There are only quite a few teachers who are really equipped with teaching experience and practical ability based on the teaching staff construction standard of "double-qualified teachers" required by the state for higher vocational education.

\section{E. Ignorance of Cultivation of Students' Humanistic Quality and Healthy Psychology}

Some non-intellectual and non-technical factors such as concept of value, morality level, character, emotion and so on have been ignored as higher vocational education pays more attention to cultivation of students' professional ability and technical application. Low requirements of students' moral educational objectives has resulted in their low humanistic quality, excessive display of personality, and even lack of cooperative awareness and collective spirit. The concept of talents shall be transformed and the cultivation of students' humanistic quality and healthy psychology shall be strengthened in China's higher vocational education in facing the situation of China's entering into WTO and the arrival of knowledge economy times in combination with current situation of China's higher vocational education and our national conditions.

\section{ESTABLISHMENT OF THE CUltivation Mode OF} CHINA's HIGHER VOCATIONAL ART \& DESIGN TALENTS IN NEW ERA

Based on the recognition of history, current condition and characteristics of the professional system for cultivation of high-skilled art \& design talents, and with a view of the cultivation requirements for talent quality in 21 st century, and in combination with our college's practical experience in recent years, this paper holds the opinion that the cultivation mode construction of high-skilled art \& design talents shall start with the following aspects:

\section{A. Aiming at Market When Setting up Majors}

Major-setup shall be connected with the market while taking market demands as its guidance on the basis of occupational post (groups) to determine talent cultivation target.

Major is the belt for higher vocational art \& design education to be closely integrated with market, and it is a joint for cultivating tens of thousands "high-quality design professionals" and "high-quality design laborer", as a result, it is very important to set up majors accurately and reasonably as it is a basic requirement for the development of a college. The college shall adjust specialty structure reasonably, transform traditional majors, and develop newly emerging industry in combination with requirements of its location, relevant industries as well as economic and social development both at home and abroad in accordance with the principle of "setting up flexibly and coexistence of majors from wide and narrow sense", to provide applicable talents whom the market needs.

B. Reform the Curriculum System and Teaching Content, Establish and Design a Curriculum Structure That Pays Attention to Practical Teaching Segment and Occupational Skills in Line with Requirement for HighSkilled Talents Cultivation

Teaching contents and curriculum are critical for realizing talent cultivation objectives. Cultivation of the occupational ability shall be realized in the occupational environment, and the teaching environment shall close to occupational environment as far as possible. Higher vocational art \& design education shall restructure curriculum system on the basis of occupational ability cultivation.

C. Pay Attention to Exploration of Teaching Mode, with Emphasis on Training of Application Skills of

Knowledge and Technology and the Cultivation of Operational Capability

Put emphasis on students' mastering of knowledge and skills through practical experience and that is what we generally said "unity of teaching, learning and practicing". For instance, our college has established a Training Room 
for Costume-Majors simulating the workshop of garment enterprises for major of costume design, and has formulated effective and scientific practical teaching operating mechanism, enabling students to practice while learning, with the theory and practical teaching conducted alternatively. Major of environmental art \& design in college also pays attention to connection between practice and teaching with emphasis on cultivation of operational capability.

\section{Establish Integrated Teaching Mode Taking Students as} Main Body, and Adopt Different Teaching Methods on the Basis of Different Teaching Characteristics Between Technical Course and Art Course

Technical course advocates the heuristic, inquiry-based and discussional teaching methods, with emphasis on combination of course teaching and project practice, and infuse high tech achievements in a timely manner, enabling students to learn in training center and the base of production, learning and research, so as to "simultaneously use the hands, brain and mouth", "unify the teaching, learning and practice".

\section{E. Strengthen Construction of Teaching Staff of "Double- Qualified Teachers"}

Teaching staff is critical for both realizing teaching plan of higher vocational art \& design education and running the higher vocational education with features. Due to the particularity of the formation of China's higher vocational art $\&$ design education, such characteristics as low level of education, unreasonable structure, weak operational capability, insufficient knowledge update, serious brain drain, low enthusiasm in teaching are exist in teaching staff. As a result, teaching staff shall be strengthened from the following aspects to accelerate development of higher vocational art \& design education:

1) Adopt the method of "invite in and dispatch out" to resolve the problems of lack of fieldwork experience and practical experience as well as weak operational ability existing in teachers of current vocational school. On one hand, engineering technicians with higher education level, high technical title and profound practical experience of the enterprises in cooperating to run colleges may be taken into consideration to be invited to teach in the college. And on the other hand, provide opportunities to teachers enabling them to go deep into enterprises and reality to learn about production equipment, process technology as well as scientific and technical information. Meanwhile, conduct development and service in combination with enterprises, to guide the teaching, enrich teaching contents and enhance teaching quality using their own achievements. And colleges may widen teachers' horizon and enhance their actual operational ability through such approaches as dispatching teacher to visit and learn in foreign countries, and taking exercises in various major enterprise by holding a post therein.

2) Formulate strict appraisal system and methods on the basis of nature and characteristics of the major. Carry out qualification assessment annually at college and school levels respectively. And teachers who have passed the assessment with qualification of "double-qualified teachers" shall be awarded a qualification certificate by the school uniformly. Implement the policy of "professional teachers shall be employed with certificates" gradually.

3) The critical measure is to strengthen training of professional teachers' professional skills. For instance, carrying out professional skills assessment, schoolenterprise connection, taking exercise in the front line of production, accelerate construction of training bases, training the students with providing them a post, transforming consumption training to production training. Holding a professional skills competition among teachers is of significant importance to do well in teaching staff construction in vocational education and to promote vocational education reform.

\section{F. Strengthen Cooperation of Production, Learning and Research, Create Talent Cultivation Features}

Currently, the idea of China's higher vocational education development is further cleared, namely, to walk out a service-oriented way that combines production, learning and research while taking employment as its guidance. Cultivating talents by combination of production, learning and research, namely jointing together the society, industry, enterprise and college to cultivate talents, is an important approach to cultivate higher vocational talents, and the inevitable requirement for the development of higher education itself.

Higher vocational art \& design education shall insist to face the society based on its own industry, and to walk out a school-running path of admission, employment and combination of production, learning and research, enable the concept, mechanism and approach of combination of production, learning and research to be fully displayed in the process of school-running. Our college has obtained obvious achievements through active exploration and practice based on the mode, mechanism and operation mode of production, learning and research cooperation education, providing large quantity of high-tech application professionals in the front line of production, management and service for social, industrial and regional economy construction, enabling our college steps into a healthy development road. The modes of cooperation of production, learning and research are as follows:

1) Set up "Major Management Committee" to serve the major reforms and curriculum construction actively. In order to cultivate talents as per demands, higher vocational colleges shall closely cooperate with enterprises, and to reasonable conduct reforms of specialty structure, curriculum system and teaching system in accordance with changes in industrial structure and occupational post development as well as the needs for cultivating students' practical skills, in combination with regional economic development requirements. And widely listen to the suggestions for talent cultivation program by staffing department heads of enterprises and the experts, pay attention to feedback form enterprise to the graduates, thus to make the talents 
cultivated by higher vocational colleges meet the actual need of the society, industry and enterprises. Our college has established three Major Management Committees consisting of personages form our college and other colleges in accordance with major categories based on requirements of our college's general development planning and major construction. Members of the committee from other colleges are heads, scholars and experts from the technical department of the industry and enterprise. Members of each Major Management Committee hold a discussion meeting regularly in our college, to provide policy-making consultations for major reforms, curriculum construction, production and teaching combination, and construction of training bases inside and outside our college and so on.

2) To teach in production, and to produce in teaching. Our college has conducted positive exploration in comprehensively cultivating the practical ability of teachers and students to combine teaching and production, namely to teach in production, and to produce in teaching, and we have gained gratifying achievements.

Through this professional training of combination of "production-teaching", teachers' ability of operation and complex problem settlement is enhanced while greatly strengthened students' skills. Every student who has positively participated in school uniform making can find a suitable job after graduating and adapt to the post requirements quickly and are favored by the employers. Through such practical activity of combination of "production, learning and research", students' actual operational ability is cultivated, learning of theory knowledge is perfected, and their correct outlook on life and values is established, with combination of theory and practice realized and their thirst for professional knowledge of costume enhanced, thus a sound foundation for students to enter into society has been laid.

3) Clear the school-running idea of "employmentoriented", and try to conduct the "order-oriented" talent cultivation mode. "Order-oriented" talent cultivation is an effective carrier for school-enterprise cooperation, and an important form for close combination of production, learning and research. As the specific implementing form for talent cultivation by cooperation between school and enterprise, order-oriented education is beneficial to reform of higher vocational education system and talent cultivation mode, enabling the teaching contents in school meet society demands, and shortening the duration for talent cultivation, improving talent cultivation quality, as well as the talents cultivated more qualified for enterprise production reality, so as to radically settle the problem of "difficult to find a job fitting his/her major".

4) Establish steady training base outside college to create a genuine occupational practice environment for students. The advantage of higher vocational graduates lies in their strong occupational awareness and operational ability and they are capable to work directly. And this advantage is determined by the well-equipped and well-operated training base and the occupational practice environment created by the colleges through various means to some extent.
5) Greatly enhance the teaching and research ability of teachers. Writing papers, compiling treatises and conducting teaching and scientific researches are ladders for growth of teachers of higher vocational colleges, and a must for intensification and leaping forward of teachers' comprehensive quality, professional knowledge and skills. In order to conduct the work of production, learning and research in an even better manner, our college has formulated a series of measures in combination with its own actual condition, and carried out accountability, which drastically mobilized teachers' positivity with remarkable teaching and scientific research outcomes, enabling the teaching and scientific research in our college to move forward with stead strides.

\section{CONCLUSION}

Higher vocational education of art \& design is an important and basic part within art education category, which assumes the tasks of supplying and delivering the higher vocational art \& design talents needed in state spiritual civilization construction and material civilization construction. Accelerating cultivation for art talents, and fully satisfying the strong demand for talents by the newly emerging industries in large quantity resulted from the flourishing economy and extensive application of computer design technique are the most urgent tasks for various higher vocational colleges currently.

\section{REFERENCES}

[1] Luo Qin: Construction and Development Exploration of Art \& Design Specialty in Higher Vocational College. Published in New West, 2007, Volume 18.

[2] Ma Shuchao: Current Condition and Development Trend of Higher Vocational Education. Published in Teaching in Northwest, Volume 9.

[3] Feng Minggao: Reflection on Talent Cultivation Mode of Higher Vocational Art \& Design. Published in Contemporary Education Forum, 2005, Volume 8.

[4] Zhang Jun: Discussion on Talent Cultivation Mode of Art \& Design Specialty in Higher Vocational College. Published in Journal of Huaibei Vocational and Technical College, December 2005. 